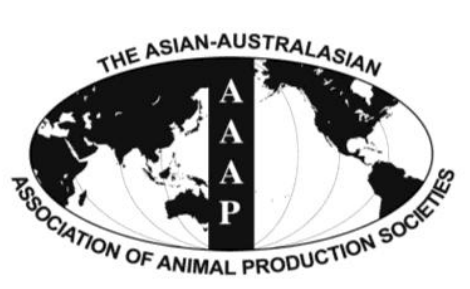

\title{
Bruising in Slaughter Cattle and Its Relationship with Creatine Kinase Levels and Beef Quality as Affected by Animal Related Factors
}

\author{
T. Mpakama, A. Y. Chulayo, and V. Muchenje* \\ Department of Livestock and Pasture Science, University of Fort Hare, \\ P. Bag X1314, Alice, Eastern Cape, South Africa
}

\begin{abstract}
The objective of the study was to determine the effects of animal related factors on bruising in slaughter cattle, creatine kinase (CK) and beef quality. Three hundred and twenty one cattle from three breeds (108 Bonsmara, 130 Beefmaster and 83 Brahman) were used in this study. The animals were grouped as follows: Group 1 (16 months old), Group 2 (18 months old) and Group 3 (24 months old). At exsanguinations, blood samples for CK determination were collected using disposable vacutainer tubes. Muscularis longissimus thoracis et lumborum (LTL) was collected $24 \mathrm{~h}$ after slaughter to determine the colour ( $\mathrm{L}^{*}, \mathrm{a}^{*}$, and $\left.\mathrm{b}^{*}\right)$ and $\mathrm{ultimate}^{\mathrm{pH}}$ $\left(\mathrm{pH}_{\mathrm{u}}\right)$ of beef. Breed, sex and age had significant effects $(\mathrm{p}<0.05)$ on bruising score, CK levels and beef quality. Bonsmara breed had the highest $(80 \%)$ bruising score percentage, $\mathrm{CK}(705.3 \pm 80.57 \mathrm{U} / \mathrm{L})$ and $\mathrm{pH}_{\mathrm{u}}(6.3 \pm 0.05)$ values while the Bonsmara had the highest $\mathrm{L}^{*}$ $(24.8 \pm 0.78) \mathrm{a}^{*}(17.5 \pm 0.53)$ and $\mathrm{b}^{*}(12.8 \pm 0.53)$ values. Higher CK levels were also observed in winter compared to summer, spring and autumn respectively. Therefore, animal factors (sex, breed and animal age at slaughter) contribute to the development of bruises and have an effect on the levels of CK and meat quality. It was also concluded that there is no significant relationship between meat parameters $\left(\mathrm{L},{ }^{*} \mathrm{a}^{*}\right.$, and $\mathrm{b}^{*}$ ) and CK levels. (Key Words: Age at Slaughter, Beef Quality, Bruising, Creatine Kinase, Meat pH, Season)
\end{abstract}

\section{INTRODUCTION}

Transportation is an important activity of the farming industry. During transportation, beef cattle are grouped by their age, size and breed which are described as intrinsic factors. Grouping of these animals is done by the farm and abattoir workers. This process involves rounding up, kraaling, loading, transportation and off-loading at the abattoir (Bonney, 2006; Chulayo et al., 2012). Transportation is associated with numerous risks which include management, intrinsic and extrinsic factors; of these, intrinsic factors have been found to significantly affect the level of bruising and the quality of meat and carcass characteristics (Hoffman and Lühl, 2012). Bruising in slaughter cattle is described as a superficial discoloration

\footnotetext{
* Corresponding Author: Voster Muchenje. Tel: +27-40-6022059, Fax: +27-86-628-2967, E-mail: vmuchenje@ufh.ac.za Submitted Aug. 8, 2013; Revised Oct. 14, 2013; Accepted Nov. 23, 2013
}

due to haemorrhage of tissue from ruptured blood vessels beneath the surface of the skin (Strappini et al., 2010; Vimiso, 2010; Vimiso and Muchenje, 2013). In the contusions, the blood accumulates in the surrounding tissues, producing pain and swelling (Blood and Studdert, 1988). Bruising occurs at the farm, during transportation and at the slaughterhouse. It is speculated that sex of animals, gender and breed has an effect on animal stress. Male and young animals are at risk of more bruising than female and old animals, due to rough driving and mishandling before and after transportation (Parrot et al., 1994; Jarvis et al., 1995; Averos et al., 2008).

Cattle are prone to repeated rough handling in their lifetime which later on lead to aversive reactions such as stress and bruising immediately prior to transportation (EFSA, 2011). Stressed and bruising in animals results in an increase in the activity of creatine kinase in the blood and this is due to tissue damage and poor muscular tissue reperfusion (Knowles et al., 1999; Vojtic, 2000). In addition,

Copyright @ 2014 by Asian-Australasian Journal of Animal Sciences This is an open-access article distributed under the terms of the Creative Commons Attribution Non-Commercial License (http://creativecommons.org/licenses/by-nc/3.0/) which permits unrestricted non-commercial use, distribution, and reproduction in any medium, provided the original work is properly cited. 
capture, loading and transportation induces permeability of the muscle membrane hence increased creatine kinase (CK) levels in the blood (Warriss et al., 1995; Lopez et al., 2006; Guardia et al., 2009). CK is found in the skeletal muscles of animals and it is responsible for maintaining energy homeostasis at the sites of high adenosine tri-phosphate (ATP) (Diene and Storey, 2009; Chulayo and Muchenje, 2013). This enzyme is generally utilized as an indicator of physical stress and/or muscle damage in animal production. In goats, higher levels of $\mathrm{CK}$ in the plasma may also be caused by breed temperament, excitability and fighting against each other (Grzyb and Skorkowski, 2005).

The aforementioned factors, especially transportation, are documented to likely have a greater adverse effect on the welfare of calves than on mature (>17 to 19 months) age animals (Zhang et al., 2005). Grandin (2001) indicated that calf welfare is mostly affected when they are exposed to a multitude of novel and stressful events during handling and transportation. This is also witnessed by the increased incidence of mortality once they arrive at the slaughterhouse (Fike and Spire, 2006). Moreover, old animals experience similar welfare challenges which later reduce carcass quality and meat quality resulting in low economic value (Grandin, 2001). The adverse effects of transportation on welfare vary by animal type. For example, mature cattle $(>500 \mathrm{~kg}$ ) such as transported for about 400 $\mathrm{km}$ for slaughter had less shrinkage, deaths and bruising compared to young animals (Grandin, 2007). Therefore, poor beef quality may be influenced by the activity undertaken by the animal prior to slaughter. Beefmaster, Bonsmara, Brahman and Nguni are breeds that can withstand adverse environmental conditions (hot temperatures), long dry periods, diseases and parasites (Beatty et al., 2006; Ndlovu et al., 2008; Marufu et al., 2011). Breed affects meat quality during transportation. Aggressive breeds are more prone to bruising, injuries resulting in carcass damage and poorer meat quality (Voisinet et al., 1997).

Several studies indicate that stress lowers post mortem ultimate $\mathrm{pH}\left(\mathrm{pH}_{\mathrm{u}}\right)$ values due to depletion of glycogen in ruminants and produces tougher meat. On the other hand pre-slaughter stress results in higher $\mathrm{pH}_{\mathrm{u}}$ and darker cuts (Devine et al., 2006; Gregory, 2010). However, there is little or no information on the relationship between creatine kinase $(\mathrm{CK})$ and meat quality attributes (ultimate $\mathrm{pH}$ and colour). The effects of animal handling and welfare during transportation of animals from farms to commercial abattoirs have been investigated (Gispert et al., 2000; van de Water et al., 2003; Liste et al., 2008; Huertas et al., 2010). In addition, studies (Martinezo-Cerezo et al., 2005; Muchenje et al., 2009) have been conducted to determine the occurrence of bruises in cattle from the farm to the abattoir however, the level of bruising and the relation to CK values was not considered. Therefore the objective of the study was to determine the effects of animal related factors on bruising in slaughter cattle, levels of creatine kinase $(\mathrm{CK})$ and the quality of beef.

\section{MATERIALS AND METHODS}

\section{Description of the study site}

The study was conducted in East London Abattoir which is located in Buffalo City Municipality. The abattoir is situated at longitude and latitude $32.2^{\circ} \mathrm{S}$ and $27.5^{\circ} \mathrm{E}$ in the Amathole District of the Eastern Cape Province of Republic of South Africa (RSA). The area has vegetation that ranges from grassland and thicket to forests and bush veld with Themeda trianda and Digitaria eriantha being the most dominant grass species. The area receives approximately $850 \mathrm{~mm}$ of rainfall per year of which most falls during the summer months (November, December and January). The day temperature during for the period of study ranged from $10^{\circ} \mathrm{C}$ to a high of $36^{\circ} \mathrm{C}$, averaging about $22.3^{\circ} \mathrm{C}$. The topography of the area is naturally flat with few steep slopes.

\section{Animal management}

Data was collected from 321 cattle over four seasons (winter, spring, summer and autumn) between the year 2011 and 2012. The seasons were categorised into the months as follows: winter (June to August), spring (September to October), summer (November to February) and autumn (March to May). All cattle were slaughtered at the East London commercial abattoir in the Eastern Cape Province. This abattoir operates from 0600 to $1700 \mathrm{~h}$ on Mondays till Fridays. On arrival at the abattoir the three breeds of cattle; Bonsmara, Brahman and Beefmaster were identified according records from the farmers. The numbers of animals per breed were 108 Bonsmara, 130 Beefmaster and 83 Brahman respectively. The animals used were both male and females and grouped according to age categories as follows: Group 1 (16 months), Group 2 (18 months) and Group 3 (24 months).

The cattle were transported by the owners from the farms to the abattoir. Transportation time (departure, arrival time and distance travelled), lairage duration, number of animals per pen, slaughtered animals per day and daily temperature were all recorded. On arrival at the abattoir, 27 offloading activities were monitored and cattle were given water ad-libitum prior to slaughter. Cattle were then slaughtered using commercial standard procedures of the abattoir. The captive bolt method was used to stun the animals, using a voltage of $300 \mathrm{~V}$, a current of 5 A for 40 to $45 \mathrm{~s}$ at a pulse 12 beats/s. 


\section{Blood collection and plasma separation}

The blood samples were collected from the animals using labelled disposable vacutainer tubes. The blood samples were placed in ice packs prior to creatine kinase (CK) analysis. A centrifuge machine (model: 5403 Centrifuge Geratebay Eppendorf $\mathrm{GmbH}$, Engelsdorp Germany) was used to centrifuge blood samples at 3,550 $\mathrm{rpm}, 21^{\circ} \mathrm{C}$ for $10 \mathrm{~min}$. Plasma was then separated and inserted into $1.5 \mathrm{~mL}$ Eppendorf tubes using pipettes and stored at $-20^{\circ} \mathrm{C}$.

\section{Creatine kinase level determination}

The serum samples were used to determine the levels of CK at the National Health Laboratory Services (NHLS), Port Elizabeth using Model DXC 600 machine (Beckman Coulter, Ireland). The contents included $2 \times 61$ ML CK Reagent, 1 preparation insert and the reactive ingredients included creatine phosphate, disodium Salt $461 \mathrm{mmol} / \mathrm{L}$, nadide 30: $0 \mathrm{mmol} / \mathrm{L}$, adenosine-5-diphosphate, monopotassium salt, dihydrate $36.0 \mathrm{mmol} / \mathrm{L}$, glucose 24.0 mmol/L, glucose-6-phosphate dehydrogenase $46.1 \mathrm{kU} / \mathrm{L}$ and hexokinase $136 \mathrm{kU} / \mathrm{L}$. All the ingredients were added for quantitative determination of $\mathrm{CK}$ activity of units per litre (U/L) in plasma.

\section{Bruise measurements}

Only carcasses that had bruises were considered. The assessment was done using a method based on the Australian Carcass Bruise Score System (Anderson and Horder, 1979). Bruise scores were calculated for each load by multiplying the number of bruises in each size class by a weighting factor: slight 1 , medium 3 , and heavy 5 , and adding these values (Anderson and Horder, 1979). The bruise scores were then divided by the number of cattle per load to give a mean bruise score per animal for each load. Bruise age was estimated using the method of Gracey et al. (1999) as shown in Table 1.

\section{Meat quality measurements}

The Muscularis longisimus thoracis et Lumborum (LTL) were used for ultimate $\mathrm{pH}$ and colour $\left(\mathrm{L}^{*}, \mathrm{a}^{*}\right.$, and $\left.b^{*}\right)$ measurements. The muscle was removed by cutting a sample between the 4 th and 6th ribs of the loin region while

Table 1. Colour observations used to estimate the age of bruises

\begin{tabular}{lc}
\hline Observable colour of the bruise & $\begin{array}{c}\text { Estimated age of } \\
\text { the bruise in hours }\end{array}$ \\
\hline $\begin{array}{l}\text { Red and haemorrhagic (bright-red) } \\
\text { Dark- red colour }\end{array}$ & $\begin{array}{c}0 \text { to } 10 \mathrm{~h} \text { old } \\
\text { Approximately } 24 \text { h old }\end{array}$ \\
$\begin{array}{l}\text { Watery consistency } \\
\text { Rusty orange colour, }\end{array}$ & 24 to $38 \mathrm{~h}$ \\
soapy to touch, clear yellow mucus & $+72 \mathrm{~h}$ (3 days old) \\
\hline Gracey et al. (1999).
\end{tabular}

Gracey et al. (1999). the carcass was still hanging, prior to vacuum-packing and storing in a cooler box an hour after collection and further storing in the refrigerator at $-4^{\circ} \mathrm{C}$.

\section{Colour measurement}

Colour of the meat $\left(\mathrm{L}^{*}=\right.$ lightness, $\mathrm{a}^{*}=$ redness and $\mathrm{b}^{*}$ = yellowness) for the Bonsmara, Beefmaster and Brahman carcasses was determined from the Muscular longissimus thoracis et. Lumborum (LTL) $24 \mathrm{~h}$ after slaughter using a colour-guide 45/0 BYK-Gardener GmbH machine with a 20 $\mathrm{mm}$ diameter measurement area and illuminant D65-day light, 100 standard observer. Three readings were taken by rotating the Colour Guide 900 machine between each measurement, in order to obtain a representative average value of the colour. This guide was calibrated each day before taking measurements using the green standard.

\section{Determination of meat $\mathbf{p H}$}

Meat pH 24 from Bonsmara, Beefmaster and Brahman of carcasses was measured from the Muscularis longissimus thoracis et lumborum muscle at the level of the 10th rib 24 $\mathrm{h}$ after slaughter on carcasses that were stored at 0 to $3^{\circ} \mathrm{C}$. The measurement was carried out using a portable $\mathrm{pH}$ meter (CRISON pH 25, CRISON Instruments, SA Spain). The pH meter was calibrated using $\mathrm{pH} 4, \mathrm{pH} 7$ and $\mathrm{pH} 9$ standard solutions (CRISON Instrument, SA Spain) before each day's measurement. The measurements were then performed with a sharpened metal sheath to prevent probe breakage and meat contamination.

\section{Statistical analysis}

The PROC GLM of Statistical Analysis System (SAS) Institute (2003) was used to analyse the effect of breed, age, gender and season on the activity of creatine kinase and bruising score. The model used was as follows:

$$
\mathrm{y}_{i j k l}=\mu+\alpha_{i}+\beta_{j}+\lambda_{k}+\mathrm{G}_{l}+\varepsilon_{i j k l m} \text { where, }
$$

$\mathrm{y}_{i j k l}=$ response variable (creatine kinase, bruising score and bruise age)

$\mu=$ constant mean common to all observations

$\alpha_{i}=$ effect of breed

$\beta_{j}=$ effect of age group (Group 1, 2, and 3)

$\lambda_{k}=$ effect of season, $\mathrm{G}_{l}=$ effect of gender and $\varepsilon_{i j k l m}=$ random error

Significant differences between least square group means for $\mathrm{CK}$ and animal factors were compared using the Duncan's procedure. Pair-wise comparison of LS means for creatine kinase concentration, sex, breed and animal age at slaughter were done using PDIFF.

The effect of breed, age group and season on $\mathrm{CK}, \mathrm{pH}_{\mathrm{u}}$, $\mathrm{L}$, ${ }^{*} \mathrm{a}^{*}$, and $\mathrm{b}^{*}$, were analysed using Proc GLM of SAS 
(2003). The stastical model used as follows:

$$
\mathrm{y}_{i j k}=\mu+\alpha_{i}+\beta_{j}+\lambda_{k}+\varepsilon_{i j k l}
$$

where,

$\mathrm{y}_{i j k l}=$ Response variables $\left(\mathrm{CK}, \mathrm{pH}_{\mathrm{u}}, \mathrm{L}, \mathrm{a}, \mathrm{b}\right.$ and WBSF $)$

$\mu=$ Overall mean

$\alpha_{i}=$ breed effect (Bonsmara, Beefmaster and Brahman)

$\beta_{j}=$ age group effect (Group 1, 2, and 3)

$\lambda_{k}=$ seasonal effect (summer, winter, spring and autumn)

$\varepsilon_{i j k l}=$ random error term

The significant difference between least square group means for CK levels and beef quality parameters were compared using Duncan multiple range procedure. Correlations were computed using PROC GLM of Statistical Analysis System (SAS) (2003) to determine the relationship between pre-slaughter condition on $\mathrm{CK}$ and meat quality attributes.

\section{RESULTS AND DISCUSSION}

\section{The effect of breed on the levels of plasma creatine kinase}

The Bonsmara (Table 2) breed had significantly higher $(705.3 \pm 80.57 \mathrm{U} / \mathrm{L})$ creatine kinase $(\mathrm{CK})$ levels than Brahman (461.8 $\pm 80.63 \mathrm{U} / \mathrm{L})$, and Beefmaster breed $(657.4 \pm 80.63 \mathrm{U} / \mathrm{L})$ respectively. The higher CK activity in Bonsmara indicate that the breed was more susceptible to stress before slaughter and also could have been due to rough driving and mishandling before and after transportation (Broom et al., 1996; Averos et al., 2008). Warries et al. (1995) and Early et al. (2010) highlighted that animals transported for periods of between 5 to $15 \mathrm{~h}$ are susceptible to stress which increases the activity of creatine kinase. The reaction of this breed to longer transportation is perplexing because it has been highlighted that Bonsmara are able to withstand harsh and unfamiliar conditions (Ndlovu et al., 2008). However, if animals are transported for longer hours they have reduced plasma CK levels if they are given feed and water at the lairages.

The lower the CK levels in Brahman and Beefmaster showed that these two breeds were not susceptible to stress

Table 2. Least square means $( \pm \mathrm{SE})$ for the effect of breed on activity of creatine kinase cattle at slaughter

\begin{tabular}{lc}
\hline Breed & CK $(\mathrm{U} / \mathrm{L})$ \\
\hline Bonsmara $(\mathrm{n}=108)$ & $705.3 \pm 80.57^{\mathrm{a}}$ \\
Beefmaster $(\mathrm{n}=130)$ & $657.4 \pm 73.85^{\mathrm{ab}}$ \\
Brahman $(\mathrm{n}=83)$ & $461.8 \pm 80.63^{\mathrm{b}}$ \\
\hline $\mathrm{a}, \mathrm{b}$ Means in the same column with different superscripts are significantly \\
different at $* \mathrm{p}<0.05$. & \\
$\mathrm{n}=$ Total number of animals. $\mathrm{CK}=$ Creatine kinase. $\mathrm{U} / \mathrm{L}=$ Units per litre.
\end{tabular}

during transportation as compared to Bonsmara breed. This is because these are synthetic breeds which can adapt well to handling and adverse environmental conditions (Beatty et al., 2006). The activity of CK increases in the blood after tissue damage, poor muscular tissue reperfusion, decreased heat and fatigue; apparently as a result of an increase in the permeability of the muscle membranes induced by capture, loading and transportation (Lopez et al., 2006; Guardia et al., 2009). Furthermore, other animals also are susceptible to transport stress leading to highest levels of $\mathrm{CK}$ in the blood (Yu et al., 2009).

\section{Effect of sex and age on plasma creatine kinase levels}

Male animals had the highest CK values $(\mathrm{p}<001)$ compared to female animals as shown in Table 3. Males were more stressed than females and this agrees with the study by Mota-Rojas et al. (2006) which indicated that the sex of the animal has an effect on the response of the animal to stress. This is because male animals are more excitable, aggressive and stress sensitive than females. Therefore, that could be the reason of increased plasma activity of $\mathrm{CK}$ found in steers transported for 12 to $16 \mathrm{~h}$. Similar results were reported by Neal et al. (2009) who reported that male humans had higher levels of CK.

Creatine kinase levels were higher $(\mathrm{p}<0.05)$ in 18 months old animals than in 16 and 24 months old animals as shown in Table 3. According to Smith et al. (1998) the different levels of $\mathrm{CK}$ in the older animals is not well understood although it might be due to muscle fatigue as a result of strenuous exercise. Similarly, the CK levels in 16 month old animals was higher $(\mathrm{p}<0.05)$ than in 24 month old. Young animals are poorly adapted to cope with transportation related stress thus it results in high rates of injuries. Young animals respond to transportation stress by increasing their body temperature, heart rate and plasma cortisol concentration (Steinhardt and Thielscher, 1999). The findings of the current study are similar to those reported by Parrot et al. (1994), who observed that young

Table 3. Least square means ( \pm SE) for the effect of sex and age of animal on the activity of creatine kinase levels of cattle at slaughter

\begin{tabular}{lcc}
\hline Variables & $\mathrm{N}$ & CK (U/L) \\
\hline Sex & & \\
$\quad$ Females & 222 & $579.3 \pm 13.65^{\mathrm{b}}$ \\
$\quad$ Males & 91 & $724.6 \pm 21.31^{\mathrm{a}}$ \\
Age & & \\
$\quad 16$ months & 116 & $636.6 \pm 76.83^{\mathrm{b}}$ \\
18 months & 85 & $729.6 \pm 89.75^{\mathrm{a}}$ \\
24 months & 112 & $524.1 \pm 78.19^{\mathrm{c}}$ \\
\hline a,b,c Means in the same column with different superscripts are significantly \\
different at* $<0.05$. \\
$\mathrm{N}=$ Total no. of animal per breed. CK = Creatine kinase. \\
U/L = Units per litre.
\end{tabular}


animals are at risk of more bruising than older animals resulting in high levels of CK. This is also linked with CK in muscles as it is expressed in higher levels in males and younger animals (Neal et al., 2009).

\section{Effects of season on bruising score and the levels of plasma creatine kinase}

Results on the effect of season on the bruising score and CK levels are shown in Table 4. Creatine kinase (CK) was higher during the winter season $(704.1 \pm 43.85 \mathrm{U} / \mathrm{L})$ and lower in the summer season $(181.3 \pm 124.09 \mathrm{U} / \mathrm{L})$, while spring $(698.3 \pm 59.19 \mathrm{U} / \mathrm{L})$ and autumn $(658.0 \pm 116.25 \mathrm{U} / \mathrm{L})$ had intermediate CK levels. Knowles et al. (1998) observed similar results and found that CK levels were higher in winter season due to poor pre-slaughter conditions. However, other authors reported an increased CK values in lambs as a result of physical stress during summer (Lowe et al., 2002; Miranda-de la Lama et al., 2011). Wilson et al. (1990) and Liu et al. (2008) reported that vigorous physical activity and high temperatures had an effect on CK level.

Autumn had the highest $(\mathrm{p}<0.05)$ bruising score (1.86 \pm 1.07$)$, while winter $(1.44 \pm 0.13)$ and spring $(1.32 \pm 0.54)$ had intermediate scores and the summer season had the least bruising score $(1.12 \pm 0.11)$ as shown in Table 3 and 4. Seasonal factors mainly temperature and humidity also seem to play a role on the prevalence of bruises. Results from this study concur with Gosalvez et al. (2006) and dalla Costa et al. (2007), who found that cold weather combined with precipitation, increased the mean number of bruises per animal, although the reasons are still unclear.

\section{Effect of breed on meat quality}

Ultimate $\mathrm{pH}$ was significantly affected by the breed of cattle as shown in Table 5. Beef from Beefmaster and Brahman breeds had significantly higher $(\mathrm{p}<0.05) \mathrm{pH}_{\mathrm{u}}$ values of $6.3 \pm 0.05$ and $6.1 \pm 0.06$, respectively compared to that of the Bonsmara breed which had an average value of 5.6 \pm 0.05 . The $\mathrm{pH}_{\mathrm{u}}$ levels of Bonsmara were within the optimal range and similar to those reported by Muchenje et al. (2008). Different temperament found within an individual breed can influence meat quality due to inherent genetic parameters. The findings of this study are similar to the findings by Grandin (1997), Mormede et al. (2002),

Table 4. Least square means $( \pm \mathrm{SE})$ for effects of season on bruising score and CK levels of cattle

\begin{tabular}{llc}
\hline Season & Bruising score & Creatine kinase (U/L) \\
\hline Spring & $1.32 \pm 0.54^{\mathrm{b}}$ & $698.3 \pm 59.19^{\mathrm{a}}$ \\
Summer & $1.12 \pm 0.11^{\mathrm{c}}$ & $181.3 \pm 124.09^{\mathrm{b}}$ \\
Winter & $1.44 \pm 0.13^{\mathrm{b}}$ & $704.1 \pm 43.85^{\mathrm{a}}$ \\
Autumn & $1.86 \pm 1.07^{\mathrm{a}}$ & $658.0 \pm 116.25^{\mathrm{a}}$
\end{tabular}

$\overline{a, b, c}$ Means in the same column with different superscripts are significantly different at $* \mathrm{p}<0.05$.

$\mathrm{U} / \mathrm{L}=$ Units per litre.
Table 5. Effects of breed on ultimate $\mathrm{pH}$, colour of meat and the activity of creatine kinase from beef cattle $( \pm$ SEM)

\begin{tabular}{lccc}
\hline \multirow{2}{*}{ Parameters } & \multicolumn{3}{c}{ Breed } \\
\cline { 2 - 4 } & Bonsmara & Beefmaster & Brahman \\
\hline $\mathrm{N}$ & 108 & 130 & 83 \\
$\mathrm{CK}(\mathrm{U} / \mathrm{L})$ & $705.3 \pm 80.57^{\mathrm{a}}$ & $657.3 \pm 73.85^{\mathrm{ab}}$ & $461.8 \pm 80.63^{\mathrm{b}}$ \\
$\mathrm{pH}_{\mathrm{u}}$ & $5.6 \pm 0.05^{\mathrm{b}}$ & $6.3 \pm 0.05^{\mathrm{a}}$ & $6.1 \pm 0.06^{\mathrm{a}}$ \\
$\mathrm{L}^{*}$ & $24.8 \pm 0.78^{\mathrm{a}}$ & $24.6 \pm 0.71^{\mathrm{a}}$ & $21.7 \pm 0.89^{\mathrm{b}}$ \\
$\mathrm{a}^{*}$ & $17.5 \pm 0.53^{\mathrm{a}}$ & $16.8 \pm 0.53^{\mathrm{a}}$ & $13.2 \pm 0.66^{\mathrm{b}}$ \\
$\mathrm{b}^{*}$ & $12.8 \pm 0.53^{\mathrm{a}}$ & $11.0 \pm 0.49^{\mathrm{a}}$ & $9.6 \pm 0.61^{\mathrm{b}}$ \\
\hline
\end{tabular}

$\overline{\mathrm{a}, \mathrm{b}}$ Means in the same row with different superscripts are significantly different at* $\mathrm{p}<0.05$.

$\mathrm{pH}_{\mathrm{u}}=$ Ultimate $\mathrm{pH} . \mathrm{L}^{*}=$ Lightness. $\mathrm{a}^{*}=$ Redness. $\mathrm{b}^{*}=$ Yellowness.

$\mathrm{CK}=$ Creatine kinase. $\mathrm{U} / \mathrm{L}=$ Units per litre. $\mathrm{N}=$ Total number of animals per breed.

Fazio and Ferlazo (2003) who reported that breed temperament influence the degree to which animals respond to stress.

The higher $\mathrm{pH}$ values obtained from Beefmaster and Brahman could be due to stress prior to slaughter, rough handling, inclement temperatures or anything that causes the animal to draw on its glycogen reserves before slaughter. These two breeds are known to have aggressive behaviour and are more prone to injuries resulting in carcass damage and poorer meat. The current results are similar to observations by Voisinet et al. (1997) and King et al. (2006) who found that cattle which are highly temperamental had a high incidence of borderline dark cutters than calm cattle. Brahman breed had a significant effect $(\mathrm{p}<0.05)$ on $\mathrm{L}^{*}$ values, with darker meat than Bonsmara and Beefmaster breeds. The darker meat produced by the Brahman breed in comparison to the Bonsmara show similar trends to the findings by O'Neill et al. (2006). O'Neill et al. (2006) observed that indigenous breeds such as Bonsmara released more catecholamines than exotic breeds during the preslaughter period, causing the depletion of glycogen.

Bonsmara and Beefmaster had the highest $a^{*}$ values with Brahman having the least $a^{*}$ values. The $a^{*}$ values ranged from $17.5 \pm 0.53$ in meat from Bonsmara to $13.2 \pm 0.66$ in meat from Brahman. The $\mathrm{a}^{*}$ values from these breeds were within the normal range. This is because $\mathrm{pH}_{\mathrm{u}}$ values were fairly normal and colour is not greatly affected by pre-slaughter conditions such as transportation. Bonsmara and Beefmaster breeds had the highest $b^{*}$ values $(12.8 \pm 0.53)$ while the lowest $b^{*}$ values $(9.6 \pm 0.61)$ were found from the Brahman breed. This could be due to the extent of stress during handling and transportation depending on the temperament, handling during the journey, condition of the animal, and duration of the journey resulting in pale colour of animals.

\section{Effect of age on meat quality}

The effect of age on meat quality attributes is shown in 
Table 6. Meat from 16, 18, and 24 months old animals had no effect on $\mathrm{pH}_{\mathrm{u}}$. The $\mathrm{pH}_{\mathrm{u}}$ values were 6.1 in meat from 16 , 18 , and 24 months old. The $\mathrm{pH}_{\mathrm{u}}$ values from 16, 18, and 24 months old cattle were above the normal $\mathrm{pH}$ range. Meat with an ultimate $\mathrm{pH}$ that is above 6.0 is categorised as a dark firm dry (DFD) meat (Bartos et al., 1993; Mounier et al., 2006) with increased tenderness (Silva et al., 1999) and poor palatability (Viljoen et al., 2002; Wulf et al., 2002). This can also be attributed to the fact that an animal's behaviour differs with its age (Terlouw, 2005). The age of the group had an effect $(\mathrm{p}<0.05)$ on $\mathrm{L}^{*}$ values (Table 3 and $6)$. The $L^{*}$ values ranged from $25.2 \pm 0.71,26.6 \pm 0.83$, and $20.9 \pm 0.73$ for 16,18 , and 24 months old cattle respectively.

Darker $L^{*}$ values were observed in 24 months old animals indicating meat becomes darker with increasing animal age. These results are similar to findings by Funghi et al. (1994) who found that $\mathrm{L}^{*}$ values decreased with an increase in slaughtering age. Zhang et al. (2005) found that high $\mathrm{pH}$ meat had lower L* (lightness), $\mathrm{a}^{*}$ (redness) and $\mathrm{b}^{*}$ (yellowness) values than normal $\mathrm{pH}$ meat, indicating that high $\mathrm{pH}$ meat is darker and less brown than in normal $\mathrm{pH}$ meat. Meat from 16 month old animals had the highest $\mathrm{a}^{*}$ and $b^{*}(17.9 \pm 0.53)$ and $(12.9 \pm 0.49)$ and the meat from 24 months old animals had the least values of $(12.9 \pm 0.54)$ and $(9.3 \pm 0.51)$ respectively. Differences in meat colour has been associated with variations in intramuscular fat, moisture content and is age dependent on the muscle myoglobin content (Lawry, 1974).

\section{Effect of breed on bruising scores of beef animals}

Effect of breed on the bruising scores of slaughtered beef animals are shown in Figure 1. The Bonsmara breed had the highest percentage of non-bruised meat (88\%) and the Brahman had the lowest none bruised meat (49\%). Bonsmara also had highest percentage $20 \%$ of slightly bright red bruised meat ( 0 to $10 \mathrm{~h}$ old) while Brahman had

Table 6. Effect of age on ultimate $\mathrm{pH}$, colour of meat and the activity of creatine kinase from cattle slaughtered at the abattoir $( \pm$ SEM $)$

\begin{tabular}{lccr}
\hline \multirow{2}{*}{ Parameters } & \multicolumn{3}{c}{ Age } \\
\cline { 2 - 4 } & 16 months & 18 months & \multicolumn{1}{c}{24 months } \\
\hline $\mathrm{N}$ & 120 & 87 & 114 \\
$\mathrm{CK}(\mathrm{U} / \mathrm{L})$ & $636.9 \pm 76.83^{\mathrm{b}}$ & $729.6 \pm 89.75^{\mathrm{a}}$ & $524.1 \pm 0.63^{\mathrm{c}}$ \\
$\mathrm{pH}_{\mathrm{u}}$ & $6.1 \pm 0.05^{\mathrm{a}}$ & $6.1 \pm 0.06^{\mathrm{a}}$ & $6.1 \pm 0.05^{\mathrm{a}}$ \\
$\mathrm{L}^{*}$ & $25.2 \pm 0.71^{\mathrm{a}}$ & $26.6 \pm 0.83^{\mathrm{a}}$ & $20.9 \pm 0.73^{\mathrm{b}}$ \\
$\mathrm{a}^{*}$ & $17.9 \pm 0.53^{\mathrm{a}}$ & $17.7 \pm 0.62^{\mathrm{a}}$ & $12.9 \pm 0.54^{\mathrm{b}}$ \\
$\mathrm{b}^{*}$ & $12.9 \pm 0.49^{\mathrm{a}}$ & $11.5 \pm 0.58^{\mathrm{b}}$ & $9.3 \pm 0.51^{\mathrm{c}}$ \\
\hline
\end{tabular}

$\overline{\mathrm{a}, \mathrm{b}, \mathrm{c}}$ Means in the same row with different superscripts are significantly different at* $\mathrm{p}<0.05$.

$\mathrm{pH}_{\mathrm{u}}=$ ultimate $\mathrm{pH}$.

$\mathrm{L}^{*}=$ Lightness. $\mathrm{a}^{*}=$ Redness. $\mathrm{b}^{*}=$ Yellowness

$\mathrm{CK}=$ Creatine kinase. $\mathrm{U} / \mathrm{L}=$ Units per litre.

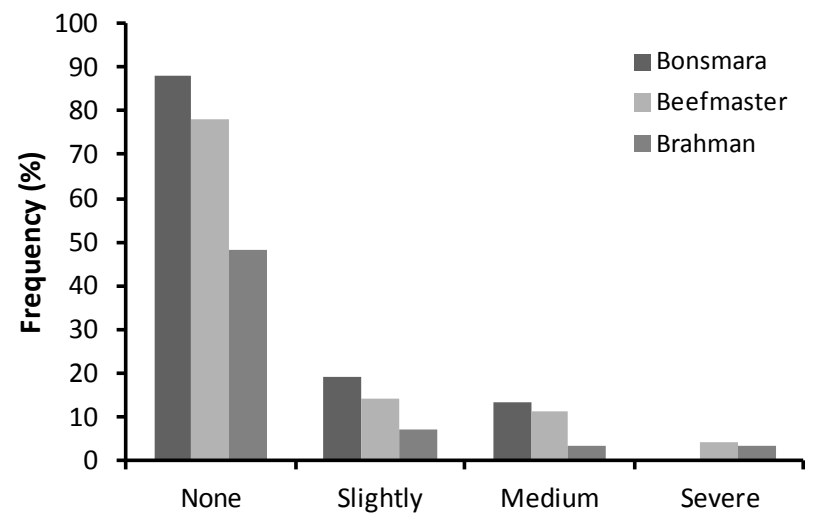

Figure 1. Effect of breed on bruising scores of slaughtered beef animals. None $=0 \mathrm{~h}$; slightly $=0$ to $10 \mathrm{~h}$ old, red and hemorrhagic (bright-red); medium $=24 \mathrm{~h}$ old, dark- red colour; severe $=24$ to $38 \mathrm{~h}$ old, watery consistency.

lowest percentage of bright red bruised meat $4 \%$. Susceptibility to bruising and temperament differs between individual animals. Fordyce et al. (1985) concluded that bruising score was beyond the breed differences. It appears that breed differences can be attributed to differences in behaviour and either being horned or hornless (Minka and Ayo, 2007).

Bonsmara had the highest percentage $10 \%$ mediumbruised dark red ( $24 \mathrm{~h}$ old) with Brahman having the lowest bruised dark red meat $5 \%$. This could have been due several injuries associated with road transportation. The level of bruising might increase with the length of journey travelled by the animals (Weeks et al., 2002). Brahman and Beefmaster breeds had the lowest percentage of severe deep bleeding bruising or injuries ( 24 to $38 \mathrm{~h}$ old).

\section{Effect of age on bruising scores of beef animals}

The highest number of slightly bright red bruises was observed in 16 month cattle while the 24 month old cattle had the lowest slightly bright bruised meat (Figure 2). The highest medium dark red bruises was observed in 16 month and lowest medium dark red bruise was observed in the 24 month old cattle. Young animals are more prone to bruising than old animals and this might have been due to increased poor handling (Strappini et al., 2009). Similar results were reported by von Holleben et al. (2009) indicating that the number heifers that had severe bruises were higher than either bulls or cows. However, contradicting results reported by Wythes and Shorthose (1991) highlighted that heavy animals had more bruising than young animals and mature ones and between old cows and old steers of the group. This therefore could mean that cattle bruising does not depend on the age of the animal but is mainly determined by the type of vehicle, duration of transport and handling methods used prior and after transport. 


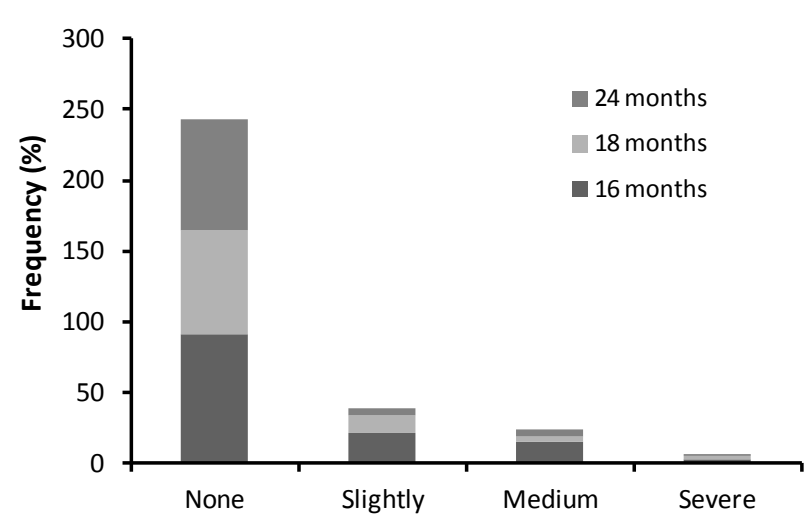

Figure 2. Effect of age on the bruising scores of cattle. None $=0$ $\mathrm{h}$; slightly $=0$ to $10 \mathrm{~h}$ old (red and hemorrhagic bright-red); medium $=24 \mathrm{~h}$ old (dark-red colour); severe $=24$ to $38 \mathrm{~h}$ old (watery consistency).

\section{Effect of sex on bruising scores of slaughtered beef animals}

Highest levels of slightly bruised meat and dark bruised meat were observed in female animals, while male animals had the lowest slightly bright bruised meat and medium dark bruised meat (Figure 3). In the literature there is evidence that female animals had higher chances for bruising than male animals (Yeh et al., 1978; Javis et al., 1995). These results are similar with Yeh et al. (1978) who found that heifers had significantly more bruises than steers and also when animals kept as separate groups, cows bruise significantly more than steers and bulls. Cows were the only class of animal where the amount of bruising increased with duration of the journey. Both male and female animals had a lower percentage of severe deep bruises.

\section{CONCLUSION}

Results from this study showed that animal factors such as sex, breed and animal age at slaughter contribute to the

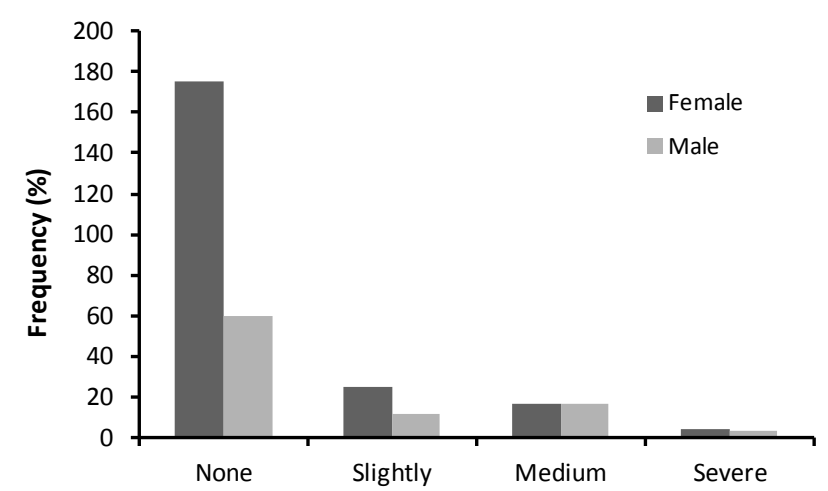

Figure 3. Effect of sex on bruising scores of cattle. None $=0 \mathrm{~h}$; slightly $=0$ to $10 \mathrm{~h}$ old (red and hemorrhagic bright-red); medium $=24 \mathrm{~h}$ old (dark- red colour); severe $=24$ to $38 \mathrm{~h}$ old (watery consistency). development of bruises, and have an effect on creatine kinase (CK) levels and meat quality. The highest percentage of slightly bruised meat was observed in Bonsmara breed, while Beefmaster and Brahman had intermediate bruising scores. Bonsmara breed had higher CK levels than Beefmaster and Brahman breeds. In addition seasonal changes also had an effect on creatine kinase and meat quality. Creatine kinase levels were higher during winter months than in spring and autumn. On the other hand, distance had a negative relationship on beef quality $\left(\mathrm{L}^{*}, \mathrm{a}^{*}\right.$, and $\mathrm{b}^{*}$ ), however no correlation was observed between distance and CK levels. It was also concluded that there is no significant relationship between meat parameters $\left(\mathrm{L},{ }^{*} \mathrm{a}^{*}\right.$, and $b^{*}$ ) and CK levels.

\section{ACKNOWLEDGEMENTS}

The authors wish to acknowledge the support received from the Meat Industry Trust fund (MIT) and Project C263. This study would not be successful without the assistance from the East London abattoir and National Health Laboratory Services.

\section{REFERENCES}

Anderson, B. and J. C. Horder. 1979. The Australian carcass bruising scoring system. Queensl. Agric. J. 105:281-287

Averos, A., S. Martin, M. Riu, J. Serratosa, and L. F. Gosalvez. 2008. Stress response of extensively reared young bulls being transported to growing-finishing farm under Spanish summer commercial conditions. Livest. Sci. 119:174-182.

Bartos, L., C. France, D. Rehak, and L. Stipkova. 1993. A practical method to prevent dark cutting (DFD) in beef. Meat Sci. 34:275-282.

Beatty, D. T., A. Barnes, E. Taylor, D. Pethick, M. McCarthy, and S. K. Maloney. 2006. Physiological responses of Bos Taurus and Bos indicus cattle to prolonged, continuous heat and humidity. J. Anim. Sci. 84:972-985.

Blood, D. C. and V. P. Studdert. 1988. Bailliere's Comprehensive Veterinary Dictionary. BailliereTindall, 24-28 Oval Road London, NWI and DX, UK.

Bonney, R. J. 2006. Farm animal welfare at work. Appl. Anim. Behav. Sci. 100:140-147.

Broom, D. M., J. A. Goode, S. J. G. Hall, D. M. Lloyd, and R. F. Parrot. 1996. Hormonal and physiological effects of a 15- hour road journey in sheep: comparison with the responses to loading, handling and penning in the absence of transport. Br. Vet. J. 152:593-604.

Chulayo, A. Y. and V. Muchenje. 2013. The effects of preslaughter stress and season on the activity of plasma creatine kinase and mutton quality from different sheep breeds slaughtered at a smallholder abattoir. Asian Australas. J. Anim. Sci. 26:1762-1772.

Chulayo, A. Y., O. Tada, and V. Muchenje. 2012. Research on preslaughter stress and meat quality: A review of challenges faced 
under practical conditions. Appl. Anim. Husb. Rural Dev. 5:16.

Dalla Costa, O. A., L. Fauctitano, A. Coldebella, J. V. Ludke, J. V. Pelso, D. Dalla Roza, and M. J. R. Parranhos da Costa. 2007. Effect of the season of the year, truck type, and location on truck on skin bruises and meat quality in pigs. Livest. Sci. 107: 29-36.

Devine, C. E., T. E. Lowe, R .W. Wells, N. J. Edwards, and J. E. H. Edwards. 2006. Pre-slaughter stress arising from on farm handling and its interactions with electrical stimulation on tenderness of lambs. Meat Sci. 73:304-312.

Diene, C. A. and K. B. Storey. 2009. Creatine kinase regulation by reversible phosphorylation in frog muscle. Comp. Biochem. Physiol. Part B. Biochem. Mol. Biol. 152:405-412.

Early, B., M. Murray, and D. J. Prendiville. 2010. Effect of road transport for up to 24 hours followed by twenty-four hour recovery on live weight and physiological responses of bulls. BMC Vet. Res. 6:38.

EFSA Panel on Animal Health and Welfare (AHAW), 2011. Scientific opinion concerning the welfare of animals during transport. EFSA J. 2011; 9:1966. pp. 125.

Fazio, E. and A. Ferlazzo. 2003. Evaluation of stress during transport. Vet. Res. Commun. 27 (Suppl.):519-524.

Fike, K. and M. F. Spire. 2006. Transportation of cattle. Vet. Clin. North Am. Food Anim. Pract. 22:305-320.

Fordyce, G., M. E. Goddard, R. Tyler, C. William, and M. A. Toleman. 1985. Temperament and bruising of Bos Indicus cross cattle. Aust. J. Exp. Agric. 25:283-288.

Funghi, R., C. Pugliese, R. Bozzi, and M. Lucifero. 1994. Evolution of performances of Chianina young bull from 6-24 months. Quality parameters of meat. 81-86, Production. 7th International Congress on Italian beef cattle contest, Perugia, Italia.

Gosalvez, L. F., X. Averos, J. J. Valdevira, and A. Herranz. 2006. Influence of season distance and mixed loads on physical and carcass integrity of pigs transported to slaughter. Meat Sci. 73:553-558.

Gispert, M., L. Faucitano, M. A. Oliver, M. D. Guárdia, C. Coll, K. Siggens, K. Harvey, and A. Diestre. 2000. A survey of preslaughter conditions, halothane gene frequency, and carcass and meat quality in five Spanish pig commercial abattoirs. Meat Sci. 55:97-106.

Gracey, J. F., D. S. Collins, and R. J. Huey. 1999. Meat Hygiene, 10th edition. Elsevier Health Science Publishers, United Kingdom.

Grandin, T. 1997. Assessment of stress during handling and transport. J. Anim. Sci. 75:249-257.

Grandin, T. 2001. Livestock handling and transport, 2nd edition, CAB International Wallingford, Oxford, United Kingdom.

Grandin, T. 2007. Livestock Handling and Transport, 3rd Edition CAB International. Wallingford Oxford, United Kingdom.

Gregory, N. G. 2010. How climatic changes could affect meat quality. Food Res. Int. 43:1866-1873.

Grzyb, K. and E. F. Skorkowski. 2005. Characterization of creatine kinase isoforms in herring (Clupea harengus) skeletal muscle. Comp. Biochem. Physiol. Part B. Biochem. Mol. Biol. 140:629-634.

Guardia, M. D., J. Estany, S. Balasch, M. A. Oliver, M. Gispert, and A. Diestre. 2009. Risk assessement of skin damage due to pre-slaughter conditions and RYRL gene in pigs. Meat Sci. $81: 745-751$.

Hemsworth, P. H., M. Rice, M. G. Karlen, L. Collega, J. N. Barnett, and G. J. Coleman. 2011. Human-animal interactions at abattoirs: Relationships between handling and animal stress in sheep and cattle. Appl. Anim. Behav. Sci. 135:24-33.

Hoffman, L. and J. Lühl. 2012. Causes of cattle bruising during handling and transport in Namibia. Meat Sci. 92:115-124.

Huertas, S. M., A. D. Gil, J. M. Piaggio, and F. J. C. M. van Eerdenburg. 2010. Transportation of beef cattle to slaughterhouses and how this relates to animal welfare and carcase bruising in an extensive production system. Anim. Welf. 19:281-285.

Jarvis, A. M., L. Selkirk, and M. S. Cockram. 1995. The influence of source, sex class and pre-slaughter handling on the bruising of cattle at two slaughterhouses. Livest. Prod. Sci. 43:215-224.

Kannan, G., Y. H. Terrill, B. Kouakow, O. S. Gazal, S. Gelaye, E. A. Amoah, and S. Samake. 2000. Transportation of goats: effects on physiological stress responses and live weight loss. J. Anim. Sci. 78:1450-1457.

King, D. A., C. E. Schuehle Pfeiffer, R. D. Randel, T. H. Jr. Welsh, R. A. Oliphint, B. E. Baird, K. O. Jr. Curley, R. C. Vann, D. S. Hale, and J. W. Savell. 2006. Influence of animal temperament and stress responsiveness on the carcass quality and beef tenderness of feedlot cattle. Meat Sci. 74:546-556.

Knowles, T. G. 1999. A review of the road transport of cattle. Vet. Rec.144:197-201.

Knowles, T. G., P. D. Warriss, S. N. Brown, and J. E. Edward. 1998. Effects of stocking density on lambs being transported by road. Vet. Rec. 142:505-509.

Lawry, R. A. 1974. Meat science. 2nd edition. Oxford, Pergamon Press.

Liu, Z. L., P. Chen, J. M. Li, S. B. Lin, D. M. Wang, L. P. Zhu, and D. P. Yang. 2008. Conjugated linoleic acids (CLA) moderate negative responses of heat stressed cows. Livest. Sci. 118:255261

Liste, M. G., G. A. María, S. García-Belenguer, G. Chacón, P. Gazzola, and M. Villarroel. 2008. The effect of transport time, season and position on the truck on stress response in rabbits. World Rabbit Sci. 16:229-235.

Lopez, O., I. Marco, J. Montane, and S. Lavin. 2006. Transport stress in Southern chamois (rupricapra pyrenaica) and its modulation by acepromazine. Vet. J. 172:347-355.

Lowe, T. E., N. G. Gregory, A. D. Fisher, and S. P. Payne. 2002. The effects of temperate evaluation and water deprivation on lamb physiology welfare and meat quality. Aust. J. Agric. Res. 53:704-714.

Marufu, M. C., L. Qokweni, M. Chimonyo, and K. Dzama. 2011. Relationships between tick counts and coat characteristics in Nguni and Bonsmara cattle reared on semiarid rangelands in South Africa. Ticks Tick Born. Dis. 2:172-177.

Minka, N. S. and. J. O. Ayo. 2007. Effects of loading behaviour and road transport stress on traumatic injuries in cattle transported by road during hot dry season. Livest. Sci. 107:9195.

Miranda-de la Lama, G. C., W. S. Sepulveda, M. Villarroel, and G. A. Maria. 2011. Livestock vehicle accidents in Spain: causes, consequences, and affects on animal welfare. J. Appl. Anim. Welf. Sci. 14:109-123. 
Miranda-de la Lama, G. C., M. Villarroel, G. Liste, J. Escos, and G. A. Maria. 2010. Critical points in the chain of (Please check again!) lamb in Spain that may compromise the animal's welfare. Small Rumin. Res. 90:174-178.

Mormede, P., H. Courvoisier, A. Ramos, N. Marissal-Avry, O. Ousova, and C. De 'saute's. 2002. Molecular genetics approaches to investigate individual variations in behavioural and neuroendocrine stress responses. Phychoneuroendocrinology 27:563-583.

Morta-Rojas, D., M. Becerril, C. Lemus, P. Sanchez, M. Gonzalez, S. A. Olmos, R. Ramirez, and M. Alonso-Spilsbury. 2006. Effects of mid-summer duration on pre- and post-slaughter performance and pork quality in Mexico. Meat Sci. 73:404412.

Mounier, L., H. Dubroeucq, S. Andanson, and I.Veissier. 2006. Varriations in meat $\mathrm{pH}$ of beef bulls in relation to conditions of transfer to slaughter and previous history of the animals. J. Anim. Sci. 84:1567-1576.

Muchenje, V., K. Dzama, M. Chimonyo, J. G. Raats, and P. E. Strydom. 2008. Meat quality of Nguni, Bonsmara and Aberdeen Angus steers raised on natural pasture in the Eastern Cape, South Africa. Meat Sci. 79:20-28.

Muchenje, V., K. Dzama, M. Chimonyo, P. E. Strydom, and J. G. Raats. 2009. Relationship between pre-slaughter stress responsiveness and beef quality in three cattle breeds. Meat Sci. 81:653-657.

Ndlovu, T., M. Chimonyo, A. I. Okoh, and V. Muchenje. 2008. A comparison of stress hormone concentration at slaughter in Nguni, Bonsmara and Angus steers. Afr. J. Agric. Res. 3:96100.

Neal, R. C., K. C. Ferdinand, J. Ycas and E. Miller. 2009. Relationship of ethnic origin, gender, and age to blood creatine kinase levels. Am. J. Med. 122:73-78.

O’Neill, H. A., E. C. Webb, L. Frylinck, and P. E. Strydom. 2006. The stress responsiveness of three different beef breed types and the effect on ultimate $\mathrm{pH}$ and meat colour. In Proceedings 52nd International Congress of Meat Science and Technology (pp.181-182). 13-18, August 2006, Dublin, Ireland.

Parrot, R. F., B. H. Misson, and C. F. De la Riva. 1994. Differential stressors effects on the concentration of cortisol, prolactin and catecholamines in the blood of sheep. Res.Vet. Sci. 56:234-239.

Statistical Analysis System. 2003. In: SAS/STATT Guide to Personal Computers, Version 6, Statistical Analysis System Institute Inc. Cary, NC, USA.

Silva, J. A., L. Patarata, and C. Martins. 1999. Influence of ultimate $\mathrm{pH}$ on bovine meat tenderness during ageing. Meat Sci. 52:453-459.

Smith, S. A., S. J. Montain, R. P. Matott, G. P. Zientara, F. A. Jolesz, and R. A. Fielding. 1998. Creatine supplementation and age influence muscle metabolism during exercise. J. Appl. Physiol. 85:1349-1356.

Steinhardt, M. and H. H. Thielscher. 1999. Maturity of suckler calves and dairy calves at the second and third week of postnatal age and forms of reaction of the animals to transport by road. Landbauforsch. Volk. 49:70-89.

Strappini, A. C., J. H. M. Metz, G. Gallo, and B. Kemp. 2009. Origin and assessment of bruises in beef cattle at slaughter. Animal 3:728-736.

Strappini, A. C., K. Frankena, J. H. M. Metz, G. Gallo, and B.
Kemp. 2010. Prevalence and risk factors for bruises in Chilean bovine carcasses. Meat Sci. 86:859-864.

Terlouw, C. 2005. Stress reactions at slaughter and meat quality in pigs: genetic background and prior experience. A brief review of recent findings. Livest. Prod. Sci. 94:125-135.

Van de Water, G., F. Verjans, and G. Geers. 2003. The effect of short distance transport under commercial conditions on the physiology of slaughter calves; $\mathrm{pH}$ and colour profiles of veal. Livest. Prod. Sci. 82:171-179.

Viljoen, H. F., H. L. De Kock, and E. C. Webb. 2002. Consumer acceptability of dark, firm and dry (DFD) and normal $\mathrm{pH}$ beef steaks. Meat Sci. 61:181-185.

Vimiso, P. 2010. Effects of marketing channel on bruising, ultimate $\mathrm{pH}$ and colour of beef; and stakeholder perception on quality of beef from cattle slaughtered at a small holder abattoir. MSc Thesis, University of Fort Hare, South Africa.

Vimiso, P. and V. Muchenje, 2013. A survey on the effect of transport method on bruises, $\mathrm{pH}$ and colour of meat from cattle slaughtered at a South African commercial abattoir. S. Afr. J. Anim. Sci. 43:105-111.

Voisinet, B. D., T. Grandin, S. F. O'Connor, J. D. Tatum, and M. J. Deesing. 1997. Bos indicus cross feedlot cattle with excitable temperaments have tough meat and a higher incidence of borderline dark cutters. Meat Sci. 46:367-377.

Von Holleben, K., S. Henke, and T. Schmidt. 2009. Effect of transport time up to $8 \mathrm{~h}$ on physiological and biochemical stress indicators and resulting carcass/meat quality in cattle - an integrated approach. Theatre presentation, 25th August, 60th Annual Meeting of EAAP, Barcelona, Spain. Book of Abstracts No 15. 243.p.

Vojtic, I. 2000. Macro CK type 1 as a major component of serum creatine kinase activity in pregnant sheep. Small. Rumin. Res. 35:249-253.

Warriss, P. D., S. N. Brown, T. G. Knowles, S. C. Kestin, J. E. Edwards, S. K. Dolan and A. J. Philips. 1995. The effects on cattle of transport by road for up to fifteen hours. Vet. Rec. 136:319-323.

Weeks, C. A., P. W. McNally, and P. D. Warriss. 2002. Influence of the design of facilities at auction markets and animal handling procedures on bruising in cattle. Vet. Rec. 150:743-748.

Wilson, B. W., P. S. Nieberg, R. J. Buhr, B. J. Kelly, and F. T. Shultz. 1990. Turkey muscle growth and focal myopathy. Poult. Sci. 69:1553-1562.

Wulf, D. M., R. S. Emnett, J. M. Leheska, and S. J. Moeller. 2002. Relationship among glycolytic potential, dark cutting (dark, firm and dry) beef, and cooked beef palatability. J. Anim. Sci. 80:1895-1903.

Wythes, J. R. and W. R. Shorthose. 1991. Chronological age and dentition of effects on carcass and meat quality of cattle in Northern Australia. Aust. J. Exp. Agric. 31:145-152.

Yeh, E., B. Anderson, P. N. Jones, and F. D. Shaw. 1978. Bruising in cattle transport over a long distance. Vet. Rec. 103:117-119.

Yu, J., S. Tang, E. Bao, M. Zhang, Q. Hao, and Z. Yue. 2009. The effect of transportation on the expression of heat shock proteins and meat quality of $M$. longissimus dorsi in pigs. Meat Sci. 83:474-478.

Zhang, S. X., M. M. Farouk, O. A. Young, K. J. Wieliezco, and C. Podmore. 2005. Functional stability of frozen normal and high pH beef. Meat Sci. 69:765-772. 